\title{
PENGARUH KEGIATAN PUBLIC RELATIONS TERHADAP KEPUASAN INFORMASI PIALANG JAKARTA FUTURES EXCHANGE
}

\author{
THE EFFECT OF PUBLIC RELATIONS ACTIVITIES ON \\ INFORMATION SATISFACTION IN JAKARTA FUTURES EXCHANGE \\ BROKERAGES
}

\author{
Cakra Ningsih, Amalia Putri Ghaisani \\ Fakultas Ilmu Komunikasi Univ. Prof. Dr. Moestopo (Beragama), Jakarta 10270. \\ cakraningsih@dsn.moestopo.ac.id
}

\begin{abstract}
ABSTRAK
Salah satu peran public relations perusahaan adalah memberikan pelayanan informasi agar khalayak merasa puas. Tujuan penelitian untuk mengetahui besarnya pengaruh kegiatan public relations Jakarta Futures Exchange terhadap kepuasan informasi pialang. Landasan dari penelitian ini menggunakan teori kepuasan informasi dan teori Uses and Gratification sebagai penghubung antara konsep peran public relations dengan kepuasan informasi. Metode yang digunakan adalah survei dengan pendekatan kuantitaif eksplanatif. Cara mengambil sampel dengan menggunakan probability Sampling dengan teknik acak sederhana dan metode pengumpulan data menggunakan kuesioner. Populasi dalam penelitian ini adalah direksi masing-masing pialang perusahaan, dengan jumlah sampel sebanyak 38 orang. Setelah dilakukan pengujian hipotesis dengan menggunakan tehnik deskripsi statistik. Hasilnya, nilai rxy sebesar 0.765 , hal ini menunjukan bahwa nilai rxy $>0$ dengan demikian $\mathrm{H} 0$ ditolak dan Ha diterima. Artinya variabel x berpengaruh terhadap variabel y sebesar 58,6\% dengan pengaruh Kuat sedangkan sisanya sebesar 41.4\% ditentukan oleh faktor lain. Dengan demikian kegiatan Public Relations Jakarta Futures Exchange (JFX) melakukan peran dan fungsi komunikasi dengan baik.
\end{abstract}

Kata Kunci: public relations, kepuasan informasi, pialang

\begin{abstract}
One of the roles of public relations companies is to provide information services so that the public feels satisfied. The research objective is to determine the effect of the Jakarta Futures Exchange public relations activities on brokerage information satisfaction. The foundation of this research uses information satisfaction theory and Uses and Gratification theory as a link between the concept of the role of public relations and information satisfaction. The method used is a survey with an explanatory quantitative approach. How to take a sample using probability sampling with simple random techniques and data collection methods using a questionnaire. The population in this study was the directors of each company brokerage, with a total sample of 38 people. After testing the hypothesis using statistical description techniques. The result, rxy value of 0.765 , this shows that the value of rxy> $\mathrm{O}$ thus $\mathrm{HO}$ is rejected and Ha is accepted. This means that the variable $x$ affects the variable $y$ by $58.6 \%$ with a strong influence while the remaining $41.4 \%$ is determined by other factors. Thus the Jakarta Futures Exchange (JFX) Public Relations activities carry out the role and function of communication well.
\end{abstract}

Keywords: Public Relations, information satisfaction, brokerage

67 | http://ejournal.unis.ac.id/index.php/DK/index 


\section{Pendahuluan}

Komunikasi merupakan hal yang paling utama dalam kehidupan sosial manusia, dengan komunikasi terbentuk sebuah fenomena baru dalam masyarakat dan komunitas yang saling terhubung dengan informasi sehingga setiap orang dapat saling berkomunikasi untuk saling bertukar informasi untuk tujuan dan kepentingan bersama. Komunikasi adalah proses sosial di mana setiap individu menggunakan simbol-simbol untuk menciptakan dan mengambarkan suatu makna dalam lingkungan mereka (West \& Turner, 2007:5).

Dalam menyampaikan pesan atau informasi perusahaan perlu adanya public relations, (Harlow, 1976). Public Relations dalam sebuah organisasi atau perusahan memiliki fungsi manajemen untuk memberikan pembinaan, bagaimana memelihara hubungan yang baik antara perusahaan dengan khalayaknya, bagaimana menjalankan komunikasi yang baik, bekerjasama dengan berbagai lini dalam perusahaan untuk memecahkan masalah, membantu pihak manajemen dalam beradaptasi dalam sebuah perubahan yang efektif, serta dapat memberi peringatan secara cepat dalam menghadapi berbagai masalah dengan melakukan riset dengan cara komunikasi yang baik dan berkepribadian sebagai hal yang utama (Ruslan, 2010:16).

Tugas utama public relations pada sebuah perusahaan adalah menjalin hubungan dengan publik internal dan eksternal perusahaan. Public relations perusahaan terlibat dengan kegiatan manajemen yang berorietasi pada kepentingan publik, mengawasi kegiatan yang dilakukan publik dan melihat reaksi publik terhadap aktivitas perusahaan, public relations menjadi jemabatan informasi antara perusahaan dengan masyarakat atau masyarakat dengan perusahaan, public relations menjadi fasilitator komunikasi yang dapat menjadi jembatan penghubung yang baik yang dapat membantu manajemen untuk mendengar apa yang diharapkan dan diinginkan oleh masyarakat terhadap perusahaan. Kepuasan konsumen tidak akan tercapai jika public relations perusahan tidak dapat menjalankan fungsinya dengan baik (Qomariah, 2012b). Salah satu usaha public relations adalah melakukan pembinaan hubungan antara masyarakat dengan perusahaan atau organisasi sehingga terbentuk kepercayaan dari masyarakat agar dapat saling menguntungkan antara masyarakat dan perusahaan (Putranto, 2003).

Eksistensi public relations dalam sebuah perusahaan sangatlah penting untuk menciptakan, memelihara, dan membangun hubungan yang baik dan harmonis antara perusahaan dengan konsumen baik internal maupun ekesternal perusahaan. Selain itu, setiap organisasi atau perusahaan akan selalu menghadapi tantangan besar untuk bisa mengelola perubahan baik yang terjadi secara internal maupun eksternal secara efektif. Dan, tentu saja turut berpengaruh pula pada pola hubungan yang telah terjalin. Manusia pada dasarnya akan memilih untuk mendapat mendapatkan pelayanan yang baik berupa barang/ produk atau jasa dengan pelayanan berkualitas dan memberikan nilai kepuasan (Tanushri \& Aibas, 2015).

Maka dari itu mengapa suatu perusahaan perlu adanya Public Relations karena sebagai penyampai informasi perlu mengetahui apakah konsumen/ publiknya merasa puas terhadap informasi yang diberikan, karena kepuasan merupakan perasaan senang yang diperoleh melalui pengorbanan.

Faktor penting dalam pemasaran adalah kepuasan pelanggan, bagaimana pemasaraan dapat memanfaatkan faktor penting tersebut (Oliver, 2007:31). Kepuasan sebagai persepsi terhadap produk atau jasa yang telah memenuhi harapannya. Konsumen/publik akan merasa puas jika persepsinya sama atau lebih dari yang diharapkan. Maka hal tersebut yang membuat Public Relations Jakarta Futures Exchange (JFX) perlu mengetahui apakah pesan yang disamapaikannya sesuai dengan persepsi yang diharapkan oleh pialangnya. 
Karena didalam pelaksanaan kegiatannya peneliti menemukan beberapa hal yang tidak sesuai dalam penyampaian informasi yang diberikan oleh Public Relations Jakarta Futures Exchange (JFX) pada pialang, yaitu belum terupdatenya data keanggotaan serta data transaksi, informasi mengenai peraturan belum diterima, keluhan terkaitan penyampaian informasi yang kurang lengkap dan jelas serta kurangnya media informasi. Oleh karena itu, Public Relations Jakarta Futures Exchange (JFX) melakukan perubahan atau cara dengan melakukan rapat atau pertemuan, lebih aktif terhadap pialang serta membuat acara agar lebih dekat dengan para pialang, namun hal tersebut dirasa belum terdapat perubahan yang signifikan oleh karena itu mengapa peneliti mengangkat masalah tersebut di dalam penelitian ini.

Dari temuan awal terkait keluhan yang dilakukan oleh pialang dengan data pada tahun 2018 yang mengeluh selama kurung waktu satu tahun berjumlah 18 orang, yang setiap bulannya jumlah yang mengeluh tidak menentu, dan pada tahun 2019 ini dari Januari-April ini sudah terhitung 3 kali keluhan pada bulan Januari 1 pialang, Maret 2 pialang (Rahatmi, Ratna. 2019, April).

Data di atas menunjukan jumlah mengeluh pada tahun 2018-2019, data tersebut diperoleh hasil dari wawancara yang dimana data setiap tahunnya tidak dapat diprediksi karena setiap bulannya tidak menentu jumlah orang yang melakukan keluhan dan para pialang melakukan keluhan melalu media tatap muka atau via telpon, sehingga tidak menentu jumlah pialang yang melakukan keluhan. Hal ini merupakan salah satu masalah dalam menyampaikan informasi terkait media penyampaiannya. Dari latar belakang yang diuraikan peneliti tertarik untuk mengangkat masalah tersebut di dalam penelitian "Pengaruh Kegiatan Public Relations Jakarta Futures Exchange (JFX) Terhadap Kepuasan Informasi pialang”.

Pembatasan masalah merupakan pembatasan ruang lingkup pemasalahan agar masalah tidak terlalu luas dan akan lebih fokus terhadap penelitian yang sedang dilakukan.

Batasan masalah berguna untuk mengidentifikasi faktor mana saja yang termasuk dalam ruang lingkup. Sesuai masalah dalam penelitian ini dibatasi kaitannya dengan kepuasan pelanggan dan kegiatan Public Relations di Jakarta Futures Exchange (JFX). Rumusan permasalahan dalam penelitian ini seberapa besar pengaruh kegiatan public relations terhadap kepuasan informasi pialang bagi Jakarta Futures Exchange. Sedangkam tujuan penelitian untuk mengetahui besarnya pengaruh kegiatan Public relations Jakarta Futures Exchange terhadap kepuasan informasi pialang.

Peneliti menggali suatu informasi dari penelitian-penelitian sebelumnya sebagai bahan acuan serta sebagai bahan perbandingan, baik mengenai kekurangan atau kelebihan yang sudah ada pada penelitian terdahulu. Selain itu, peneliti juga menggali informasi dari berbagai macam buku-buku terkait judul penelitian, maupun jurnal dalam rangka mendapatkan sebuah informasi yang akurat pada penelitian sebelumnya tentang bagaimana pada akhirnya suatu teori dapat digunakan kedalam suatu penelitian yang berkaitan dengan judul yang digunakan.

Penelitian terdahulu yang dilakukan oleh Diva Alvita pada tahun 2012 mengenai "Peran Public Relations Terhadap Loyalitas Pelanggan PT. Sarana Rima Raya". Public Relations PT. Sarana Rimba Raya menjalankan fungsi manajemen dengan baik, terutama komunikasi internal yang dilakukan sehingga para pegawai perusahaan mempunyai rasa memiliki terhadapat perusahaan dan memiliki tanggung jawab yang tinggi demi perkembangan perusahaan secara luas. Perusahaan mengharapkan agar loyalitas pelanggan sangat berdampak yaitu dengan cara perusahaan memberikan pelayanan yang memuaskan melalui dukungan fasilitas dan kemudahan dalam melakukan transaksi berskala internasional. 
Besarnya pengaruh peranan seorang public relations terhadap kesetiaan konsumen menunjukkan bahwa Peranan public relations tersebut memiliki pengaruh yang besar terhadap sebuah loyalitas. Jadi perusahaan sebaiknya melakukan peranan public relations dengan sebaik-baiknya dan terarah serta mampu support dan perhatian kepada hal pendukung yang berkaitan dengan membangun hubungan baik dengan seluruh pelanggan maka dengan demikian akan terciptalah suatu bentuk loyalitas atau kesetiaan pelanggan yang diinginkan oleh perusahaan (Alvita, 2012).

Penelitian ini menggunakan Teori Uses and Gratifications Denis McQuail 1981, teori ini menyebutkan adanya dua hal penting dibalik pendekatan ini. Pertama adalah adanya tentangan terhadap suatu asumsi yang terjadi karena keharusan mengenai efek media, yang merupakan bagian dari keharusan peran individu yang kita kenal dalam sebuah model komunikasi dua tahap. Kedua, adanya keinginan untuk lepas dari sebuah perdebatan panjang mengenai penggunaan media massa yang hanya akan didasarkan atas keinginan individu (Daryanto, 2014). Asumsi dasar dari teori manfaat dan kepuasan; 1) Audiensi adalah aktif bukan pasif, 2) Audience bebas memilih media, 3) Media bukan satu-satunya pemuas kebutuhan, 4) Seseorang dapat dibuat untuk tertarik dan memiliki motif pada kasus tertentu, 5) Pertimbangan nilai tentang signifikansi sosial dari media harus diperluas (Ardianto, 2011).

Selain menggunakan teori uses and gratification, penelitian ini juga menggunakan teori kepuasan inofrmasi. Kepuasan informasi adalah perasaan senang atau kecewa seseorang yang muncul atas dasar pemenuhan jumlah ketidakpastian yang dapat diukur dengan mengurangkannya melalui pemakaian sejumlah alternatif pilihan yang tersedia. Jadi, kepuasan informasi adalah suatu hal yang dapat mendatangkan kesenangan ataupun rasa kecewa terhadap seseorang yang muncul atas dasar pemenuhan jumlah yang tidak akan pasti yang hanya dapat diukur dengan mengurangkannya melalui pemakaian sejumlah pilihan yang tersedia.

Ada banyak metode yang biasa digunakan dalam sebuah perusahaan untuk mengukur terkait sejauh mana kepuasan pelanggannya (Kotler, 2014:102), yaitu: 1) Complaint System dan kotak Saran: setiap perusahaan pasti akan meninjau sejauh mana kepuasan pelanggan terbentuk terhadap barang ataupun jasa yang ditawarkan (customer oriented) perusahaan dituntut untuk menyediakan akses yang mudah bagi seluruh pelanggannya untuk menyampaikan baik itu berupa masukan, saran, kritik, pendapat dan keluhan mereka terhadap perusahaan karena itu dinilai sangat penting. 2) menggunakan strategi seorang Pembeli Bayangan (Ghost Shopping): mempekerjakan beberapa pembeli bayangan yang berpura-pura sebagai pelanggan produk di sebuah perusahaan dan kemudian menilai bagaimana cara perusahaan tersebut melayani permintaan pelanggannya, bagaimana menjawab pertanyaan pelanggannya dan bagaimana menangani setiap keluhan dari pelanggannya. 3) Analisis peralihan pelanggan (Lost Customer Analysis); perusahaan seharusnya dapat memiliki akses untuk menghubungi pelanggannya yang beralih ke perusahaan lain agar dapat memantau serta memahami alasan mengapa hal tersebut bisa terjadi dan agar dapat melakukan perbaikan atau penyempurnaan perusahaan yang dianggap maampu membuat pelanggan beralih ke perusahaan lain. 4) Survey Kepuasan pelanggan: melalui survey kepuasan pelanggan ini perusahaan akan mendapatkan tanggapan secara langsung dari pelanggan dan juga mampu mendapatkan kesan positif terhadap perusahaan, karena perusahaan dinilai mampu menaruh perhatian terhadap pelanggannya.

Kepuasan pelanggan adalah ujung tombak atau dapat dikatakan sebagai hal penting bagi hubungan antara pemasaran, manajemen dan sumber keunggulan yang bersifat kompetitif bagi sebuah organisasi (Claycomb, et al. 2002:99). Kepuasan 
ataupun ketidakpuasan pelanggan menjadi bagian dari pengalaman pelanggan terhadap sebuah produk yang ditawarkan. Kepuasan menurut Eboli dan Mazulla adalah gambaran atau pemahaman konsumen mengenai sebuah kualitas jasa atau produk. Jika gambaran atau pemahaman konsumen tersebut tidak merasa puas maka akan berdampak pada perilaku, gagasan serta aksi mengenai kualitas sebuah jasa atau produk tersebut. Sedangkan menurut Grembergern dan Amelinckx kepuasan konsumen adalah bagaimana keinginan yang dirasakan untuk membandingkan sebuah produk agar diterima sesuai dengan apa yang diharpakan (Moezzi, Nawaser, Shakhsian, \& Khani, 2012).

Sedangkan komunikasi merupakan salah satu aspek terpenting dalam kegiatan di sebuah perusahaan. Setiap bagian dalam perusahaan tidak dapat luput dari proses komunikasi. Bahkan tanpa komunikasi, aktivitas perusahaan pun tidak dapat berjalan sebagaimana mestinya. Komunikasi berpengaruh terhadap keberhasilan atau kegagalan atas ide yang disampaikan, sehingga dengan melalui komunikasi segala kepentingan, keinginan dan harapan-harapan baik organisasi dan khalayak pun dapat diketahui dan dimengerti. Komunikasi efektif adalah komunikasi yang dilancarkan sedemikian rupa sehingga menimbulkan efek kognitif, efek afektif dan efek konatif (behavioral) pada komunikasi sesuai dengan tujuan komunikator.

Keefektifan komunikasi ditentukan oleh kemampuan kita dalam berkomunikasi secara jelas serta mampu membentuk suatu kesan yang kita inginkan atau juga dapat dikatakan mampu mempengaruhi orang lain sesuai kehendak kita dan bagaimana suatu pesan yang disampaikan komunikator tersebut menimbulkan dampak atau efek tertentu pada komunikan. Dampak atau efek tersebut dapat dibedakan menjadi: Dampak kognitif, timbul pada komunikan yang menyebabkan dia menjadi tahu atau meningkatkan intelektualnya; Dampak efektif, yaitu tujuan komunikator ingin menggerakan hati dan menimbulkan perasaan tertentu dalam diri komunikan; Dampak konatif atau behavioral, dimana timbul pada komunikan dalam bentuk perilaku, tindakan dan kegiatan.

\section{Metode Penelitian}

Dalam penelitian ini, peneliti menggunakan paradigma positivism karena pendekatan yang digunakan penelitian ini yaitu kuantitatif. Menurut Sugiyono (2013:13) Paradigma positivism adalah paradigma yang memandang realitas suatu gejala (fenomena) itu dapat diklasifikasikan, relative tetap, konkrit, teramati, terukur dan hubungan gejala bersifat sebab-akibat.

Pendekatan ini menggunakan pendekatan kuantitaif, pendekatan kuantitatif adalah suatu pendekatan yang dilakukan untuk mendapatkan data yang dapat diukur berupa angka-angka (Kuantitaif). Penelitian dengan pendekatan kuantitatif dilakukan untuk membandingkan satu atau lebih sebuah variabel penelitian. Selain itu dikatakan juga bahwa penelitian kuantitatif dilakukan untuk mengatahui bagaimana hubungan atau pengaruh antara beberapa variabel penelitian. Penelitian kuantitatif analisis datanya dilakukan setelah data terkumpul, dengan menggunakan perhitungan (angka-angka) atau analisis statistik dan kesimpulannya berupa tingkat hubungan antar variabel. (Hamidi 2007:27).

Pendekatan kuantitatif memungkinkan para peneliti untuk menetapkan nilai-nilai numerik yang bermakna terhadap variabel penelitian dan kemudian menganalisa nilai tersebut menggunakan statistik deskriptif dan infrensial untuk menggambar data, menyimpulkan karakteristik populasi berdasarkan sifat sampel, dan menemukan perbedaan yang signifikan antara kelomppok dan hubungan antar variabel.

Penelitian sosial dapat diartikan sebagai suatu metode analisis dari situasi yang merumuskan berbagai macam masalah-masalah sosial yang terjadi di dalamnya dengan maksud untuk menemukan fenomena atau aspek baru, memahami 
bagaimana sebab musabab beserta hubungan antara keduanya, mengoreksi, melakukan verifikasi untuk memperluas pengetahuan yang semuanya sangat diperlukan dalam pengembangan teori - teori dan tindakan praktis. Jenis pada penelitian sosial yaitu, Penelitian Eksploratif, Penelitian Deskriptif, Penelitian Eksplanatif, Penelitian Verifikatif dan Penelitian Pengembangan.

Penelitian ini bersifat eksplanatif, untuk menguji hubungan antar variabel yang dihipotesiskan, dan ada hipotesis yang diuji kebenarannya. Hipotesis ini menggambarkan hubungan antara dua atau lebih variabel untuk mengetahui apakah suatu variabel berasosiasi atau tidak dengan variabel lainnya.

Tujuan penelitian ini dengan jenis eksplamatif adalah untuk mengukur dua variabel, yaitu variabel bebas dengan variabel terikatnya yang kemudian dianalisis secara kuantitatif dengan menggunakan skala likert. Selanjutnya, setelah data - data yang terkumpul dan dikelompokkan klasifikasinya, maka langkaah selanjutnya adalah penganalisaan data tersebut secara kuantitatif.

Populasi dalam penelitian ini adalah pialang Jakarta Futures Exchange (JFX) berjumlah 60 pialang. Rumus yang digunakan dalam pengambilan sampel adalah dengan rumus sederhana Taro Yamane. Pada tahun 2019 Jakarta Futures Exchange (JFX) tercatat 60 pialang yang bergabung, kemudian untuk menghitung ukuran sample berdasarkan proporsi populasi. Dari perhitungan diatas, maka dapat diketahui bahwa jumlah sampel yangdigunakan 37,5 yang dibulatkan dalam penelitian ini sebanyak 38 orang responden. Dengan demikian maka jumlah sampel pada penelitian ini adalah sebanyak 38 orang yang nantinya dapat dijadikan responden dalam penyebaran kuesioner.

Uji Validitas adalah Uji ketepatan atau ketelitian suatu alat ukur dalam mengukur apa yang sedang ingin diukur. Dalam pengertian yang mudah dipahami, uji validitas adalah uji yang bertujuan untuk menilai apakah seperangkat alat ukur sudah tepat mengukur apa yang seharusnya diukur.
Jumlah responden untuk uji validitas sebanyak 38 orang, lalu rumus yang digunakan untuk uji validitas yakni korelasi pearson product moment. Hasil data penelitian dikatakan valid apabila nilai $r$ hitung pearson product moment $>0,5$ (Sugiyono 2003:143). Rumus korelasi product moment adalah untuk menentukan instrumen valid atau tidak dengan ketentuan sebagai berikut: Jika $r$ hitung $\geq r$ tabel dengan taraf signifikansi 0,05 , maka instrumen tersebut dikatakan valid; Jika $\mathrm{r}$ hitung $<\mathrm{r}$ tabel dengan taraf sigifikansi 0,05 , maka instrument tersebut dikatakan tidak valid.

Selain uji validitas, uji reliabilitas juga dilakukan. Uji relibilitas dapat dinilai pada Cronbach's Alpha, jika nilai Alpha > 0,05 maka konstruk pertanyaan yang merupakan dimensi nilai Cronbach Alpha 0,85, di atas 0,05 yang berarti item pertanyaan Variable $\mathrm{X}$ adalah Reliable.

Uji relibilitas dapat di nilai pada Cronbach's Alpha, jika nilai Alpha > 0,05 maka konstruk pertanyaan yang merupakan dimensi nilai Cronbach Alpha 0,88, di atas 0,05 yang berarti item pertanyaan Variable $\mathrm{Y}$ adalah Reliable. Setelah uji validitas dan reliabilitas dilakukan, peneliti melakukan analisis data. Analisis data merupakan kegiatan setelah data seluruh responden atau sumber data lain terkumpul (Sugiyono 2005). Teknik analisis data menggunakan bantuan program SPSS versi 23 (Statistical Package For Social Science) melalui tahap-tahap; Editing, Coding, Tabulationg atau classifieng, dan Interpreting. (Suwarno, 2006:21).

Dalam penelitian kuantitatif analisis data merupakan kegiatan setelah data dari seluruh responden atau sumber data lain terkumpul. Data-data yang dikumpulkan dalam penelitian ini akan dianalisa dan diinterprestasikan secara kuantitaif dengan menggunakan skala likert. Adapun pengertian skala Likert adalah skala yang dapat digunakan untuk mengukur sebuah persepsi, maupun sikap atau pendapat seseorang atau kelompok mengenai suatu peristiwa atau fenomena-fenomena sosial, 
berdasarkan definisi operasional yang telah ditetapkan oleh seorang peneliti.

Dengan skala likert maka variabel yang akan diukur dijabarkan kedalam bentuk subvariabel kemudian subvariabel tersebut dijabarkan kembali dalam bentuk komponen-komponen ataupun sub-sub yang dapat terukur. "Komponen terukur tersebutlah yang kemudian dijadikan sebagai tolak ukur untuk menyusun suatu instrument, yang dapat berupa pertanyaan ataupun sebuah pernyataan yang kemudian nantinya akan dijawab oleh seorang responden. Jawaban pada setiap item tersebutlah yang digunakan oleh skala likert untuk menentukan tingkatan dari sangat positif sampai negative.

Peneliti mengambil judul "Pengaruh" maka untuk mencari bentuk hubungan dua variabel atau lebih dalam bentuk fungsi persamaan digunakan rumus persamaan Regresi Linier Sederhana. Regresi sederhana didasarkan pada hubungan fungsional ataupun kausal satu variabel independen dengan satu variabel dependen. Persamaan umum regresi linier sederhana $\Upsilon=a+b X$ (Sugiyono 2013:243).

Adapun untuk mengetahui besar kecilnya nilai variabel terikat akibat dan variabel bebas disederhanakan menggunakan rumus koefisien penentu (koefisien Determinasi); $\mathrm{KD}=(\mathrm{rxy}) 2 \times 100 \%$, Koefisien Determinasi (untuk mengetahui besarnya suatu nilai variabel yang terikat akibat dari pengaruh variabel bebasnya) rxy : Korelasi Product Moment. Dimana Analisis korelasi dilanjutkan dengan menghitung jumlah koefisien determinasi, dengan cara koefisien yang ditemukan tersebut selanjutnya dikuadratkan untuk membantu dalam mengolah data perhitungan hasil penelitian yang peneliti gunakan yaitu SPSS (Statistic Package For Social Science). Hipotesis pada penelitian ini Ho $=\mathrm{rxy}=0$ yang berarti tidak terdapat pengaruh Kegiatan Public Relation Jakarta Futures Exchange (JFX) Terhadap Kepuasan Informasi pialang dan $\mathrm{Ha}=$ $\operatorname{rxy}(\operatorname{rxy}>0) \neq 0$ yang berarti terdapat pengaruh Kegiatan Public Relation Jakarta Futures Exchange (JFX) Terhadap Kepuasan Informasi pialang.

\section{Hasil Dan Pembahasan Hasil Penelitian}

Untuk melakukan uji korelasi, peneliti menggunakan aplikasi SPSS 23 (Statistical Package For Social Science). Berdasarkan tabel 1 output diketahui sig. (2-tailed) antara kegiatan Public Relations (X) dengan kepuasan informasi (Y) adalah sebesar 0,000 $<0,05$, yang berarti terdapat korelasi yang signifikan antara variabel kegiatan Public Relations dengan variabel kepuasan informasi. Atau berdasarkan dengan $r$ hitung hubungan kegiatan Public Relations (X) dengan Kepuasan Informasi (Y) adalah sebesar 0,765 > $\mathrm{r}$ tabel 0,320, maka dapat disimpulkan bahwa ada hubungan atau korelasi antara variabel kegiatan Public Relations dengan variabel kepuasan informasi.

Tabe1. Uji Korelasi

\begin{tabular}{|c|c|c|c|}
\hline \multicolumn{4}{|c|}{ Correlations } \\
\hline & & kegiatan & $\begin{array}{l}\text { kepuasan } \\
\text { informasi }\end{array}$ \\
\hline \multirow[t]{3}{*}{ Kegiatan } & Pearson Correlation & 1 & .765 \\
\hline & Sig. (2-tailed) & & .000 \\
\hline & $\mathrm{N}$ & 38 & 38 \\
\hline \multirow[t]{3}{*}{ kepuasan informasi } & Pearson Correlation & .765 & 1 \\
\hline & Sig. (2-tailed) & .000 & \\
\hline & $\mathrm{N}$ & 38 & 38 \\
\hline
\end{tabular}


Berdasarkan hubungan antara variabel $\mathrm{X}$ dengan variabel $\mathrm{Y}$ berada pada tingkat hubungan Kuat yaitu pada level 0,765 (terletak pada wilayah 0,60 - 7,99).

Dengan demikian hipotesis yang berlaku atau yang diterima adalah $\mathrm{Ha}=\operatorname{rxy}(\operatorname{rxy}>0) \neq 0$, Ha yang berarti terdapat pengaruh Kegiatan Public Relations Jakarta Futures Exchange (JFX) Terhadap Kepuasan Informasi pialang. Maka dengan demikian $\mathrm{HO}$ ditolak dan $\mathrm{Ha}$ diterima.

Koefisien Determinasi ( $R$ Square) atau $\left(\mathrm{R}^{2}\right)$ dapat diartikan sebagai pemberi pengaruh yang diberikan oleh variabel independen atau bebas $(\mathrm{X})$ terhadap variabel dependen atau terikat (Y). Nilai koefisien determinasi ( $R$ square) dapat juga digunakan untuk meperkirakan seberapa besar kontribusi dari pengaruh variabel bebas (X) terhadap variabel Terikatnya (Y). Tujuan dari menghitung koefisien determinasi adalah untuk mengetahui seberapa besarkah pengaruh Kegiatan Public Relations Jakarta Futures Exchange (JFX) Terhadap Kepuasan Informasi pialang, dapat dilihat juga dalam tabel 2. Dari tabel 2 tersebut didapatkan nilai $\mathrm{R}$ sebesar 0.765. Tabel model summary diatas, artinya pengaruhnnya Sedang pada Kegiatan Public Relations Jakarta Futures Exchange (JFX) Terhadap Kepuasan Informasi pialang sebesar $\mathrm{R}^{2}=58,6 \%$. Sisanya yaitu $41.4 \%$ ditentukan oleh faktor lain yang tidak peneliti bahas dalam penelitian dan membutuhkan penelitian lebih lanjut.

Tabel 2 Uji Koefisien Determinasi

Model Summary

\begin{tabular}{|l|r|r|r|c|}
\hline Model & $\mathrm{R}$ & $\mathrm{R}$ Square & \multicolumn{1}{c|}{$\begin{array}{c}\text { Adjusted R } \\
\text { Square }\end{array}$} & $\begin{array}{c}\text { Std. Error of the } \\
\text { Estimate }\end{array}$ \\
\hline 1 & $.765^{\mathrm{a}}$ & .586 & .574 & 1.88223 \\
\hline
\end{tabular}

a. Predictors: (Constant), kegiatan PR

Berdasarkan tabel 3 menunjukan bahwa nilai konstanta (a) 63.740 dan Kegiatan Public Relations (total X) (b) 0.564 dengan demikian maka persamaan regresi kedua variabel tersebut adalah $\Upsilon=\mathrm{a}+\mathrm{bX}, \Upsilon=$ $63.740+0.564 X$, Jika $X=1$, Maka nilai $\Upsilon=$ $63.740+0.564=64.304$.

Jika tidak ada kegiatan Public Relations, maka kepuasan informasi pialang sebesar 63.740 Namun jika nilai kegiatan Public Relations adalah 1 maka kepuasan informasi
64.304 setiap penambahan skor 1 kegiatan Public Relations, kepuasan informasi pialang naik sebesar 64.304. Atau bisa menggunakan nilai signifikansi (sig), berdasarkan tabel 3 diketahui nilai signifikansi (sig) sebesar $0,000<0,05$, sehingga dapat di simpulkan Ho ditolak dan Ha di terima, yang berarti bahwa "Terdapat pengaruh Kegiatan Public Relations Jakarta Futures Exchange (JFX) Terhadap Kepuasan Informasi pialang".

Tabel 3. Uji Regresi Linier Sederhana

Coefficients $^{\mathrm{a}}$

\begin{tabular}{|c|c|c|c|c|c|c|}
\hline \multirow{2}{*}{\multicolumn{2}{|c|}{ Model }} & \multicolumn{2}{|c|}{ Unstandardized Coefficients } & $\begin{array}{c}\text { Standardized } \\
\text { Coefficients }\end{array}$ & \multirow[b]{2}{*}{$\mathrm{t}$} & \multirow[b]{2}{*}{ Sig. } \\
\hline & & $\mathrm{B}$ & Std. Error & Beta & & \\
\hline 1 & (Constant) & 63.740 & 5.628 & & 11.326 & .000 \\
\hline & $\begin{array}{l}\text { Kegiatan } \\
\text { PR }\end{array}$ & .564 & .079 & .765 & 7.131 & .000 \\
\hline
\end{tabular}

a. Dependent Variable: Kepuasan Informasi

\section{Pembahasan}

Hasil penelitian dimaksud agar peneliti mengkonstruksi sebuah pengetahuan melalui 
cara-cara berpikir deduktif-induktif dengan dasar metode penjelasan reflectif thingking. Menjelaskan asumsi-asumsi dasarnya, mengemukakan pikiran-pikirannya, gagasan-gagasan yang menurutnya benar berdasarkan apa yang ia yakini. Materi-materi penting dalam pembahasan adalah bagaiman menemukan hasil penelitian, landasan toeri yang akan dipakai dalam sebuah penelitian, penelitian terdahulu yang dilakukan orang lain, hasil pemikiran atau usulan orang lain, opini atau pendapat peneliti, kebutuhan pendukung atau sekunder lainnya (Bungin, 2006:183).

Dalam Pembahasan hasil penelitian ada beberapa hal penting yang perlu diperhatikan, seperti hasil temuan penting dalam penelitian perlu di lakukannya review untuk dapat memperoleh penjelasan yang sifatnya empiris dan metodologis, kemudian temuan-temuan penting ini juga harus dibahas berdasarkan teori yang digunakan dalam penelitian, Sehingga pembahasanya nanti apakah teori yang digunakan dalam penelitian ini dapat diterima, dikritik, atau bahkan dapat ditolak sama sekali. (Bungin, 2006:239)

Penelitian ini bersifat eksplanatif dengan menggunakan metode survey sebagai pencarian data. Lokasi penelitian dilakukan di kantor Jakarta Futures Exchange (JFX) oleh para Direksi masing - masing pialang. Populasi yang terdapat pada penelitian ini sebanyak 60 pialang dan sampel yang digunakan sebanyak 38 responden/direksi.

\section{Kegiatan Public Relations}

Berdasarkan hasil pengembangan variabel X (Pengaruh Kegiatan Public Relations) diperoleh nilai sebesar 2701 yaitu masuk kategori setuju/tinggi. Dari hasil nilai repitulasi mean pada variabel bebas, maka diketahui respon dari responden mengenai Peranan Public Relations Jakarta Futures Exchange (JFX) diperoleh total mean sebesar 3,95 dalam kategori tinggi, median secara keseluruhan 4 dan modus secara keseluruhan Sementara itu hasil dari penelitian terdahulu menyatakan bahwa Variabel (X) "Pengaruh Peranan Public Relations" sebesar 4,20 yang menunjukan bahwa peran Public Relations termasuk dalam kategori tinggi. (Alvita 2012), Dengan demikian maka hasil penelitian peneliti secara empirik adalah benar karena, didukung oleh hasil penelitian terdahulu, Penilitian ini didukung dengan konsep peranan Public Relations sebagai berikut :

1,Expert Prescriber, yaitu seorang Praktisi sebagai praktisi pakar yang bertugas mendefinisikan suatu masalah, mengembangkan sebuah program, dan bertanggung jawab penuh atas implementasinya. 2,Fasilitator komunikasi, Fasilitator komunikasi yang bertindak sebagai seorang perantara, interpreter, serta mampu menjadi mediator antara organisasi dan publiknya. 3,Fasilitator Pemecah Masalah, praktisi yang melakukan peran sebagai fasilitator diharapkan mampu menjadi pemecah masalah, dimana mampu berkolaborasi dan berkomunikasi dengan manajer lain untuk mendefinisikan dan memecahkan masalah-masalah yang kerap terjadi di dalam suatu perusahaan. 4.Teknisi Komunikasi, pekerjaan yang dilakukan terkait dengan komunikasi antara lain, menulis, mengedit, membuat press release, membuat website perusahaan, membuat annual report, mempersiapkan pidato dan pekerjaan teknis lainnya. 5.Monitoring, Seorang Public Relations yang berperan untuk mengantisipasi setiap perubahan yang mungkin saja terjadi dan berdampak negatif terhadap organisasi atau perusahaan. 6,Interpreter, Public Relations berperan sebagai penggerak antara manajemen dengan publik internal maupun eksternalnya, 7.Lubricant, yang dikatakn juga sebagai pelumas atau pelicin dalam menciptakan hubungan eksternal dan internal yang harmonis dan efisien. 8,Komunikasi, Media teknik komunikasi inilah yang nantinya akan sangat menentukan keberhasilan seorang Public Relations secara menyeluruh. (Lesly 1991). Dengan demikian secara teoritik hasil penelitian peneliti benar karena didukung teori yang relevan. Oleh karena itu, hasil penelitian ini secara teoritik maupun empirik 
adalah benar.

\section{Kepuasan Informasi}

Berdasarkan hasil pengembangan variabel Y (kepuasan informasi pialang) diperoleh nilai sebesar 3945. Jika diinterpretasikan masuk kategori setuju/tinggi. Maka diketahui respon dari responden mengenai kepuasan informasi pialang (Variabel Y) diperoleh total mean sebesar 3,99 dalam kategori tinggi, median secara keseluruhan 4 dan modus secara keseluruhan 4.

Menurut hasil penelitian terdahulu dari Sekar Pasastining Tyas Universitas Prof. Dr. Moestopo (Beragama) menyatakan bahwa Variabel (Y) " kepuasan informasi" sebesar 3,65 yang menunjukan bahwa Kepuasan informasi termasuk dalam kategori tinggi. Dengan demikian maka hasil penelitian peneliti secara empirik adalah benar karena didukung oleh hasil penelitian lain.

Penelitian yang dilakukan oleh peneliti dengan responden pialang, mengungkapkan jika pialang akan lebih aktif atau merespon ketika peran Public Relations Jakarta Futures Exchange (JFX) memberikan informasi secara lebih aktif, melalui media sosial yang saat ini sedang digunakan, namun tingkat kepuasan informasi yang diterima oleh pialang berbeda setiap individunya sesuai dengan teori kepuasan informasi, yang terdapat beberapa tingkat kualitas informasi: Tingkat kegunaan (Useful), Nilainya (valuable), Faktualitasnya (factual), Keterandalan (Reliable), Ketepatannya (Precision) dan Kebenarannya (Truth). Dengan demikian secara teoritik hasil penelitian peneliti juga benar karena didukung teori yang relevan. Oleh karena itu, hasil penelitian ini secara teoritik maupun empirik adalah benar.

\section{Pengaruh Kegiatan Public Relations Jakarta Futures Exchange (JFX) terhadap kepuasan informasi pialang}

Hasil penelitian analisis data dengan uji signifikansi menunjukan bahwa hasil $\mathrm{R}$ square (R2) yang didapat sebesar 0,586. Artinya terdapat pengaruh peranan Public Relations terhadap kepuasan informasi pialang yang termasuk kategori Kuat. Jadi variabel $\mathrm{X}$ berpengaruh terhadap variabel $\mathrm{Y}$ sebesar 58,6\% dengan pengaruh Kuat. Sedangkan sisanya sebesar $41.4 \%$ ditentukan oleh faktor lain yang tidak peneliti bahas dalam penelitian dan membutuhkan penelitian lebih lanjut.

Hasil dari peneliti analisis data dengan uji signifikansi dengan judul "Pengaruh Kegiatan Public Relations Jakarta Futures Exchange (JFX) terhadap kepuasan informasi Pialang" tersebut secara teori didukung dengan menggunakan konsep peranan Public Relations dan teori kepuasan informasi .Teori dan konsep ini menjelaskan bagaimana peranan Public Relations dalam tingkat kepuasan informasi.

\section{Simpulan}

Berdasarkan rumusan masalah, tujuan penelitian dan hasil penelitian serta pembahasan dalam penelitian ini maka dapat dirumuskan beberapa kesimpulan sebagai berikut: Kegiatan Public Relations Jakarta Futures Exchange (JFX) dalam melakukan fungsinya dalam kategori tinggi. Pengaruh kegiatan Public Relations menggunakan Expert Prescriber dengan pengaruh baik. Sebagai Fasilitator Komunikasi berperan baik. Sebagai Fasilitator Pemecah Masalah, berpengaruh baik. Sebagai Teknik Komunikasi berperan baik; Kepuasan informasi pialang, sudah terpenuhi secara baik.

Nilai kepuasan dilihat dari peran yang dilakukan Public Relations Jakarta Futures Exchange (JFX) dapat disusun berdasarkan nilai kepuasan dari yang tertinggi ke yang terendah adalah: Tingkat Kegunaan, Nilainya, Faktualnya, Ketepatannya, Kebenarannya, Keterandalan; Pengaruh Kegiatan Public Relations Jakarta Futures Exchange (JFX) terhadap kepuasan informasi pialang dipengaruhi sebesar 58,6\%, sisanya di 
tentukan oleh faktor lain yang tidak peneliti bahas dalam penelitian sebesar $41,4 \%$.

\section{Daftar Pustaka}

Alvita, Diva. (2012). "Pengaruh Peranan Public Relations Terhadap Loyalitas Pelanggan Area Jakarta Dalam Komoditi Ekspor Produk Kayu Olahan (Studi Kasus Pt. Sarana Rimba Raya) Periode November 2011”. Binus University Jakarta, Indonesia.

Ardianto, Elvinaro. (2011). Metodologi Penelitian untuk Public Relation. Bandung: Simbiosis Rekatama Media

Bungin, Burhan. (2006). Analisis Data Penelitian Kualitatif. Jakarta : Raja Grafindo.

Claycomb dan Martin. (2002). Building Costumer Relationship: An Inventory of Services Provider Objectives and Practices. Journal of Services Marketing. Vol. 16 No. 7 Hal. 15-35.

Daryanto. (2014). Teori Komunikasi. Malang: Gunung samudera.

Hamidi. (2007). Metode Penelitian dan Teori Komunikasi. Malang : UPT.UMM.

Harlow, Rex F. (1976). Building a Public Relations Definition. Public Relations Jogjakarta.

Kotler, Philip, Garry Armstrong. (2014). Prinsip -prinsip Manajemen. Edisi 14, jilid 1. Jakarta: Erlangga.

Lesly, Philip.(1991). Lesly's handbook of Public Relations and Communication. Chicago III: Probus Publishing Company.

Moezzi, H., Nawaser, K., Shakhsian, F., \& Khani, D. (2012). Customer relationship management ( e-CRM ): New approach to customer' 's satisfaction, 6(5), 20482055. http://doi.org/10.5897/AJBM11.1736

Oliver, Sandra. (2007). Strategi Public Relations. Jakarta: Erlangga.

Putranto, H. (2003). Public Relations Dan Citra Perusahaan. Ilmu Sosial dan Ilmu Politik Jurusan Ilmu Komunikasi Universitas Sebelas Maret Surakarta. Universitas Sebelas Maret
Qomariah, N. (2012b). Pengukuran Kepuasan dan Loyalitas Pasien Rumah Sakit Berbasis Customer Relationship Management. Managemen Universitas Muhammadyah Jember, 239-250.

Rahatmi, Ratna. (2019, April). Wawancara Pribadi.

Ruslan, Rosady. (2010). Manajemen Public Relations dan Media Komunikasi. Jakarta: Rajawali Pers.

Sugiyono. (2005). Statistik Untuk Penelitian (hal:207), Bandung; Alfabeta.

Sugiyono. (2013). Metode Penelitian Pendidikan Pendekatan Kuantitatif, Kualitatif, dan $R \& D$. Bandung: Alfabeta.

Suwarno, Wiji. (2006). Dasar-Dasar Ilmu Pendidikan. Jogjakarta : AR-Ruzz Media

Tanushri, M., \& Aibas, N. (2015). Health Services and Public Relatins in India: An Overview. Global Journal for Research Analysis, 4(6), 410-412.

West, Richard. Lynn H. Turner. (2007). Pengantar Teori Komunikasi. Jakarta: Salemba Humanika.

77 | http://ejournal.unis.ac.id/index.php/DK/index 